\title{
PEMANFAATAN IMAGE TO SPEECH BERBASIS ANDROID UNTUK PENGENALAN WARNA BAGI ANAK BAWAH TIGA TAHUN (BATITA)
}

\author{
Hero Wintolo ${ }^{1}$, Anggit Tri Widiastuti ${ }^{2}$ \\ ${ }^{1,2}$ Teknik Informatika \\ Sekolah Tinggi Teknologi Adisutjipto \\ Jalan Janti Blok-R Lanud Adisutjipto Yogyakarta \\ ${ }^{1}$ herowintolo@stta.ac.id
}

\begin{abstract}
The introduction of color to children under three years of age is done by providing and explaining objects favored by children, such as toys and food, which have certain colors so that children recognize colors at that age. Unlike adults, how to introduce color in children does require a different way, in addition to the objects and food, in this study the introduction of color in children is done by using the software that is installed on the smartphone using the image to speech. This method is expected to be more easily carried out and the results are expected to be maximum because of equipment smartphones today the price is very affordable and are often used by children ages two until three years old to play games.
\end{abstract}

Keywords: image to speech, smartphones, children

\section{Abstrak}

Pengenalan warna terhadap anak-anak yang usianya di bawah tiga tahun dapat dilakukan dengan memberikan dan menjelaskan warna pada benda disukai oleh anak-anak, seperti mainan dan makanan. Tidak seperti orang dewasa, bagaimana memperkenalkan warna pada anak-anak memang membutuhkan cara yang berbeda, di samping benda dan makanan, dalam penelitian ini pengenalan warna pada anak dilakukan dengan menggunakan perangkat lunak yang diinstal pada smartphone yang menggunakan metode image to speech. Metode ini diharapkan akan lebih mudah dilakukan dan hasilnya diharapkan akan maksimal karena smartphone peralatan saat ini harga sangat terjangkau dan sering digunakan oleh anak-anak usia dua sampai dengan tiga tahun untuk bermain game.

Kata kunci: gambar pidato, smartphone, anak-anak

\section{Latar Belakang Masalah}

Perkembangan perangkat lunak komputer mengalami peningkatan dari tahun ke tahun, peningkatan ini juga dipicu karena perkembangan perangkat lunak pada perangkat smartphone. Salah satu teknologi informasi yang banyak diguanakan dalam perangkat lunak komputer dan smartphone yaitu konversi bahasa tulisan menjadi bahasa percakapan atau 
dikenal sebagai text to speech. Proses konversi text to speech ini dapat dilakukan dengan berbagai cara, salah satunya dengan melakukan proses perekaman suara ke dalam memori sekunder. Dengan cara perekaman ini proses konversi dikembangkan untuk melakukan konversi gambar atau citra warna menjadi bahasa percakapan atau dikenal dengan nama image to speech.

Image to speech dapat dimanfaatkan untuk membantu anak-anak usia dini (antara 3-5 tahun) dalam mengenal warna-warna yang dapat mereka kenali dengan bantuan suara dari smartphone ketika sebuah obyek berwarna diletakkan didepannya. Anak usia dini yang belum mengerti warna akan kesulitan mengenali warna yang mereka lihat. Disamping guru dan orangtua yang membimbing, mereka membutuhkan alat bantu yang dapat memudahkan mereka dalam mengenali warna. Dengan alat bantu yang mudah dan menyenangkan, anakanak tersebut akan lebih mudah dalam belajar dan mengerti warna.

\section{Relasi Penelitian}

Penelitian ini mengacu pada penelitian yang sebelumnya sudah dilakukan dengan judul "Peningkatan Kemampuan Pengenalan Konsep Warna Melalui Permainan Edukatif Dengan Styrofoam Pada Anak Usia Dini Kelompok A Di TK Islam Al Fajar Surabaya (Mastija, 2013). Kemampuan pengenalan konsep warna anak kelompok A TK Islam A1 Fajar masih tergolong rendah (menyebutkan nama-nama warna, mengelompokkan warna yang sama, menyebutkan nama-nama benda yang ada di sekitar anak, mengurutkan pola berdasarkan warna) yaitu di bawah $60 \%$ dari hasil yang diharapkan oleh guru. Penelitian ini dilaksanakan dengan tujuan untuk peningkatan kemampuan pengenalan konsep warna melalui permainan edukatif dengan styrofoam pada anak usia dini kelompok A di TK Islam Al Fajar Surabaya. Hal ini dikarenakan belum pernah memakai styrofoam, mudah dibawa, tidak berbahaya dan mudah mendapatkannya. Subyek dalam penelitian ini adalah anak kelompok A TK Islam Al Fajar dengan lokasi penelitian di TK Islam Al Fajar Surabaya. Teknik pengumpulan data dalam penelitian ini dengan menggunakan observasi dan pengumpulan data. Teknis analisis data menggunakan analisis diskriptif kualitatif. Berdasarkan hasil penelitian dapat disimpulkan bahwa permainan edukatif dengan styrofoam dapat meningkatkan kemampuan pengenalan konsep warna pada anak usia dini kelompok A TK Islam Al Fajar karena berdasarkan analisis data yang telah dilaksanakan mulai dari analisis data siklus satu sampai dengan analisis data siklus dua diketahui bahwa rata-rata peningkatan dari 40\% menjadi 97\%. Kemampuan pengenalan konsep warna melalui permainan edukatif dengan styrofoam pada anak usia dini kelompok A TK Islam Al Fajar Surabaya mengalami peningkatan secara bertahap yakni dari kemampuan pengenalan konsep warna kurang menjadi baik setelah diadakan penelitian.

\section{Metodologi Penelitian}

\subsection{Studi Literatur}

Pada tahap ini dilakukan pencarian dan pemahaman literatur yang berhubungan dengan penelitian. Sedangkan literatur yang digunakan berasal dari: karya ilmiah, buku referensi, jurnal dan prosiding.

\subsubsection{Image to Speech}

Image to speech dalam judul penelitian ini mengandung makna sebagai sebuah aplikasi speech yang digunakan untuk mendengarkan kata atau kalimat yang diucapkan oleh peralatan (hardware) bukan manusia. Bahasa yang digunakan dapat menggunakan bahasa 
yang sudah dikenal dan digunakan manusia, ini sangat tergantung dengan bahasa yang digunakan secara mayoritas dalam sebuah komunitas atau negara, sehingga speech dalam bahasa Indonesia sangat mudah dibangun dengan menggunakan perangkat lunak komputer.

Speech dalam aplikasi yang dibuat menggunakan perangkat lunak komputer dapat berupa suara yang mirip manusia atau suara manusia yang direkam dan diputar saat algoritma dalam aplikasi tersebut sedang berjalan. Speech yang pertama kali dikenal yaitu text to speech yang merupakan speech untuk membaca tulisan dalam bentuk text menjadi sebuah suara yang dapat di dengar melalui indera telinga manusia.

\subsubsection{Text to Speech}

Text to speech atau juga dikenal sebagai speech synthesis merupakan suara buatan, bukan suara rekaman seperti pada voice response systems yang bekerja dengan merangkai susunan kata terpisah (isolated word), speech synthesis memproduksi sinyal ucapan secara otomatis melalui transkripsi grafem ke fonem pada kalimat yang diberikan. Sehingga Text to speech melakukan dua pekerjaan utama, yang pertama menganalisis text dan kedua membuat sintesa ucapan terhadap text yang dianalisis tersebut (lihat Gambar 1).

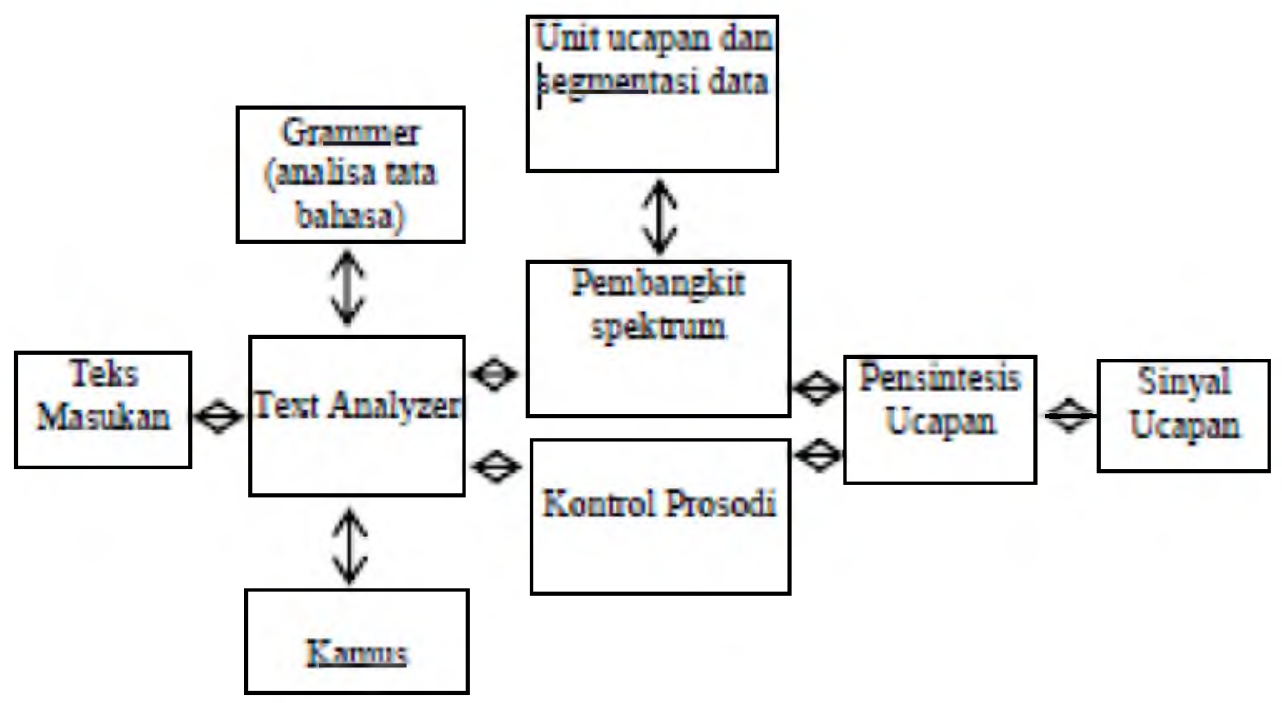

Gambar 1. Diagram Sistem Text-to-Speech Synthesis

(Sumber Iwan Iwut Tritoasmoro, 2006)

Dua pekerjaan dalam Text to speech dikenal juga sebagai cara melakukan konversi digunakan untuk memproses teks, yang dituliskan dalam kode program yang menggunakan bahasa pemrograman java. Program ini, melakukan proses pengambilan gambar menggunakan kamera, hanya dapat dijalankan menggunakan smartphone berbasis android. Ketika program dijalankan, kamera dari smartphone diarahkan pada sebuah obyek yang memiliki warna, kemudian dalam waktu tidak lebih dari 5 detik, gambar akan di capture, dan warna yang ada pada obyek tersebut akan diproses dalam bentuk text, dari proses ini text to speech diterapkan sehingga pada speaker smartphone akan terdengar suara dari warna tersebut. Sehingga dapat dikatakan bahwa image to speech yang digunakan dalam aplikasi ini sebenarnya adalah modifikasi dari text to speech yang ada pada smartphone android. Diagram use-case dari image to speech disajikan pada Gambar 2. 


\subsubsection{Smartphone Android}

Smartphone pada dasarnya merupakan alat komunikasi yang dikenal sebagai telepon seluler atau telepon tanpa kabel atau telepon yang dapat dibawa oleh pemiliknya dengan berpindah-pindah tempat. Meski dapat dikatakan sama secara fungsinya ketika digunakan untuk melakukan komunikasi audio, smartphone memiliki perbedaan dengan jenis telepon seluler lainnya. Dengan smartphone, seseorang dapat melakukan komunikasi audio dan video serta menjelajah jaringan internet, yang tidak mungkin dilakukan dengan telepon seluler generasi pertama dan kedua. Dan peralatan telekomunikasi ini dapat bekerja jika ada perangkat lunak yang dipasangkan didalamnya. Perangkat lunak ini mirip sistem operasi dalam sebuah komputer, tetapi dengan pengurangan beberapa fungsi dan penambahan pada fungsi telekomunikasinya. Salah satu sistem operasi yang paling banyak digunakan saat ini pada smartphone yaitu android. Screenshot dari smartphone android ditampilkan pada Gambar 3.

Android merupakan sebuah sistem operasi yang hanya digunakan pada mobile device seperti smartphone. Android ini merupakan sebuah nama perusahaan android.inc yang kemudian di akuisisi oleh Google pada pertengahan tahun 2005 dan mengubah nama penyedia aplikasi Android dari Android market menjadi Google play. Dengan menggunakan sistem open sources yang memungkinkan para pengembang untuk menciptakan beragam perangkat lunak menarik yang dapat dinikmati oleh para penggunanya, seperti game, chatting dan lain-lain. Sehingga smartphone berbasis android ini lebih murah harganya dari gadget sejenis. Dan sistem operasi android telah mengalami beberapa perubahan dan perbaikan dengan nama seperti nama-nama makanan.

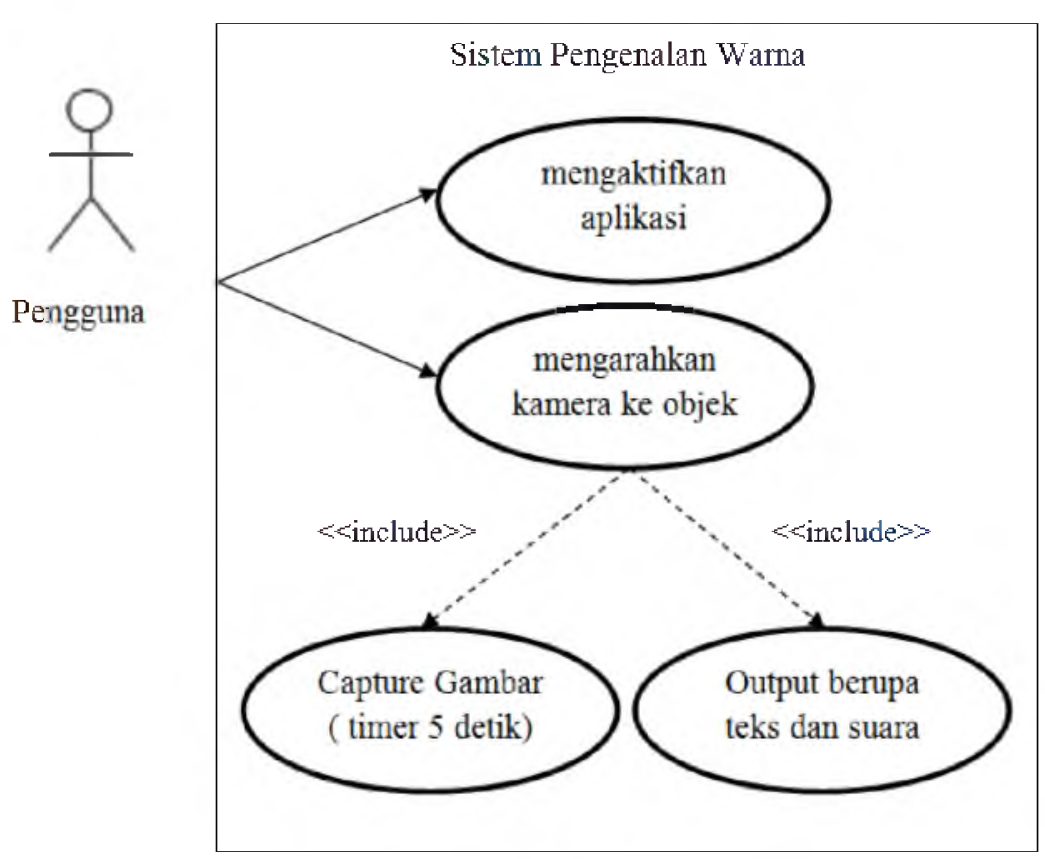

Gambar 2. Use-case diagram untuk image to speech 


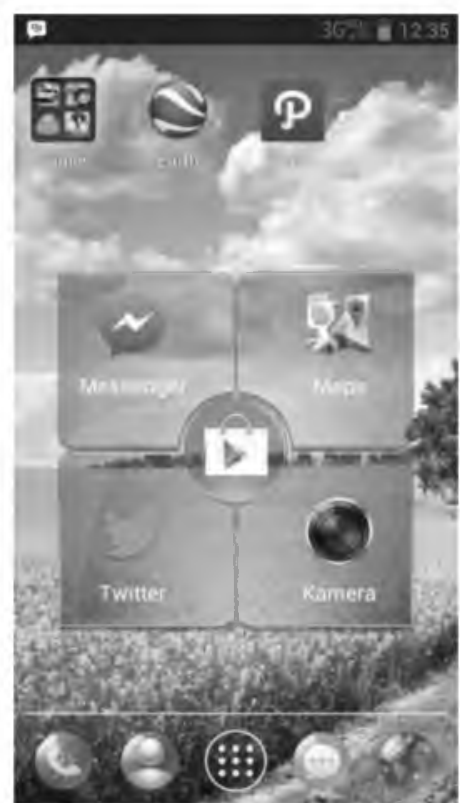

Gambar 3. Screenshot smartphone android

\subsubsection{Pengenalan Warna Pada Citra Digital}

Warna merupakan elemen penting dari sebuah gambar/ citra yang ditampilkan perangkat lunak yang menggunakan sistem operasi berbasis visual atau Windows. Windows sudah menyediakan warna RGB yang dapat diuraikan menjadi 3 warna dasar, yaitu Merah (Red), Hijau (Green), dan Biru (Blue). Ketiga warna dasar dapat dicampur menjadi warnawarna yang berbeda. Tiap komponen, baik red, green dan blue, mempunyai 256 tingkat intensitas warna (dari 0 sampai dengan 255), sehingga dari kombinasi ketiganya akan membuat 16 juta lebih warna yang berbeda. Masing-masing warna dasar memiliki range antara 0 dan 255, di mana 0 adalah minimal (gelap) dan 255 adalah maksimal (terang). Misalnya komponen $\mathrm{R}$ bernilai 255 sedangkan $\mathrm{G}$ dan $\mathrm{B}$ bernilai 0 , maka warna yang dihasilkan adalah merah. Jika masing-masing komponen bernilai 255 maka hasilnya putih dan ketiganya 0 berarti hitam.

Warna dasar ini diilustrasikan sebagai sebuah kubus dalam koordinat Cartesian, (lihat Gambar 4) dengan masing-masing sumbu mewakili harga dari komponen-komponen $\mathrm{R}, \mathrm{G}$, dan B. Sudut-sudut kubus yang berhimpit dengan sumbu-sumbu koordinat ditempati oleh warna-warna merah, hijau, dan biru yang disebut juga dengan warna primer. Sedangkan sudut-sudut kubus yang lainnya ditempati oleh warna-warna sian, magenta, dan kuning yang disebut juga dengan warna sekunder. Pada kubus ini, warna hitam terletak pada sudut kubus di posisi $(0,0,0)$, dan warna putih pada posisi $(255,255,255)$.

\subsection{Perancangan Perangkat Lunak Object Oriented Programming (OOP)}

Pada tahap ini dilakukan perancangan untuk melakukan pengambilan obyek dan otomatis melakukan pengambilan obyek setiap interval waktu 5 detik. Semua data atau fungsi dipecah-pecah dan dibungkus dalam kelas-kelas atau obyek-obyek, kemudian antar kelas dikoneksikan pada program utama dengan cara memanggilnya. Dalam perancangan perangkat lunak dikenal ada dua cara, yang pertama dengan Water Fall dan yang kedua dengan Object Oriented Programming (OOP). Aplikasi yang dirancang dan digunakan pada 
penelitian ini menerapkan metode OOP. Dalam metode ini perangkat lunak yang dirancang dalam bentuk modul kecil-kecil yang kemudian disatukan dalam aplikasi intinya. Aplikasi ini dirancang pada sebuah komputer yang memiliki perangkat keras (hardware) dan perangkat lunak (software). Hardware adalah perangkat keras (alat) yang bisa dilihat dan diraba oleh manusia secara langsung yang mendukung proses komputerisasi.

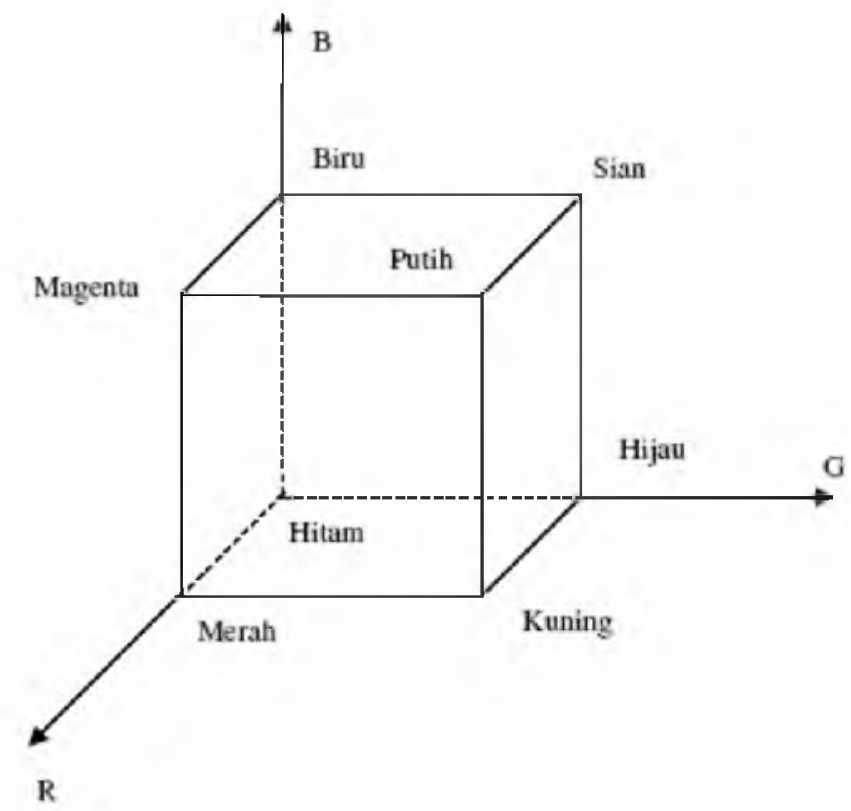

Gambar 4. Model warna RGB

Beberapa kebutuhan perangkat keras yang digunakan dalam pembuatan aplikasi Obtion Remote Versi 1.0 ini adalah:

1. Laptop: Lenovo B490 Intel Core i3 $31102.4 \mathrm{Ghz}+14^{\prime \prime}$ Display $+2 \mathrm{~GB}$ Ram $500 G B$ HDD + VGA nVidia Geforce GT705M IGB

2. Handphone: Oppo r8113 OS Android Jelly Bean v4.1 + Prosesor Dual Core $1 G H z+R A M 512 M B$

Sedangkan perangkat lunak yang dibutuhkan saat merancang aplikasi tersebut adalah: Sistem Operasi Microsoft Windows 7, sebagai sistem operasi yang digunakan pada komputer:

1. Sistem Operasi Android, sebagai sistem operasi yang digunakan pada handphone. Android.

2. Android Development Tools sebagai tools untuk membuat aplikasi berbasis

Dengan menggunakan perangkat keras dan perangkat lunak tersebut aplikasi yang digunakan untuk membaca warna ini dirancang terlebih dahulu bentuk tampilannya (lihat Gambar 5). Setelah tampilan dibuat, maka selanjutnya dengan menggunakan Android Development Tools berupa perangkat lunak yang bernama Eclipse aplikasi pembaca warna ini dibuat dan dituliskan kode programnya. Dengan hanya satu tampilan, aplikasi yang dirancang ini akan menahan kamera smartphone dalam waktu lima detik sebelum mengambil gambar. Waktu tersebut diukur dengan cara menghitung waktu mengaktifkan aplikasi saat obyek berwarna sudah didekatkan pada kamera smartphone. 


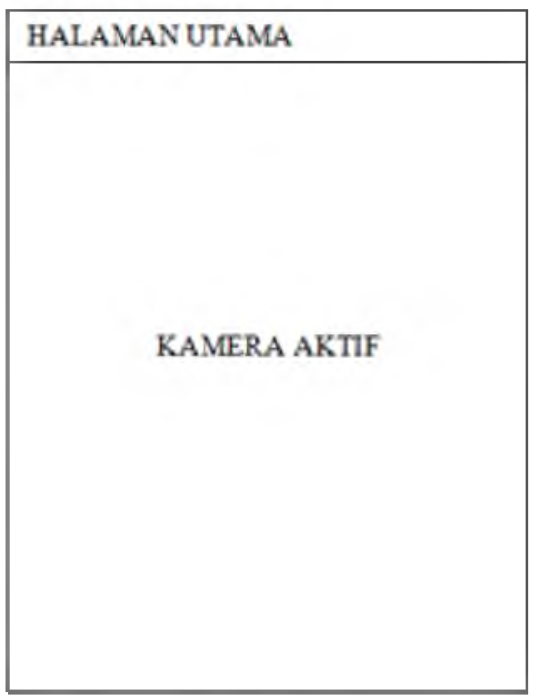

Gambar 5. Tampilan interface aplikasi image to speech

\subsection{Prinsip Kerja Sistem}

Setelah melalui proses rancangan, selanjutnya penelitian ini memasuki tahap pengujian, dan sebelum pengujian dilakukan, berikut perangkat lunak hasil rancangan yang digunakan dalam tahapan pengujian. Lihat Gambar 6, perangkat lunak yang digunakan dalam tahap pengujian merupakan hasil rancangan yang dibuat menggunakan bahasa pemrograman java dan diberi nama Pengenalan Warna. Perangkat ini diapasangkan pada sebuah smartphone yang sebelumnya memasukan file apk dari perangkat lunak ini, kemudian diinstalasikan dan kemudian dapat digunakan.

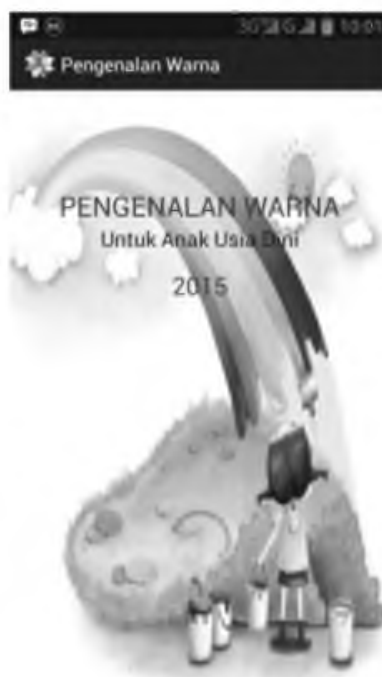

Gambar 6. Tampilan perangkat lunak Pengenalan Warna

Perangkat lunak pengenalan warna ini akan aktif setelah ikon dari perangkat lunak diaktifkan pada smartphone, kemudian akan mengambil gambar pada posisi perangkat lunak 
seperti pada Gambar 7. Pada posisi perangkat lunak seperti gambar ini, kamera akan diaktifkan secara otomatis dan gambar di depan kamera akan diambil secara otomatis juga.

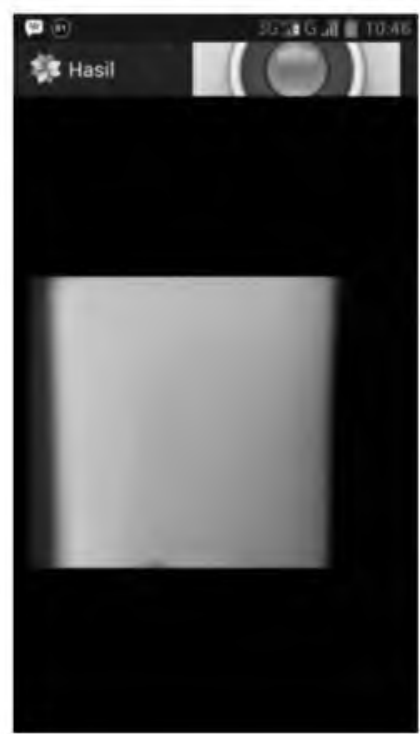

Gambar 7. Proses pengambilan gambar menggunakan perangkat lunak Pengenalan Warna

Setelah obyek diambil gambarnya menggunakan kamera dengan perangkat lunak pengenalan warna ini, gambar akan dianalisis warnanya. Hasil analisis warna akan memunculkan pesan pada smartphone yang menggunakan perangkat lunak pengenalan warna seperti tampak pada Gambar 8.

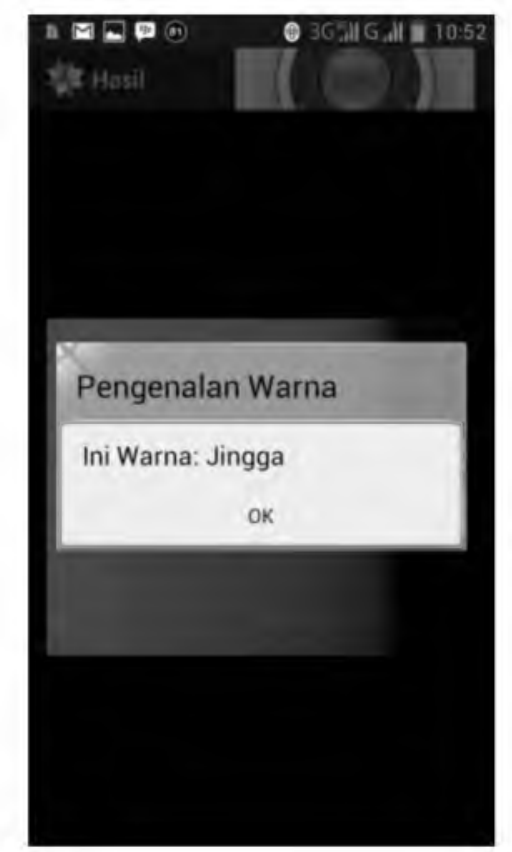

Gambar 8. Pesan warna dari pengambilan gambar menggunakan perangkat lunak Pengenalan Warna 


\section{Hasil dan Pembahasan}

Pengujian yang pertama kali dilakukan untuk menguji aplikasi untuk membaca warna pelangi, dengan melakukan pengujian setiap warna sebanyak 30 kali. Hal ini diharapkan agar perangkat lunak yang dirancang dapat diketahui tingkat keberhasilannya saat membaca warna. Kamera yang digunakan dengan lensa $5 \mathrm{Mega}$ Pixel dengan warna pelangi yang ditampilkan dalam layar monitor komputer Liquid Crystal Display (LCD). Data hasil pengujian dibuat dalam prosentase dimana kebenaran/ $10 \times 100 \%$ ditampilkan pada Tabel 1 .

Tabel 1. Tingkat keberhasilan dalam pengenalan warna

\begin{tabular}{|l|l|l|l|}
\hline No & Warna & Koordinat warna dalam RGB & Tingkat Keberhasilan \\
\hline 1 & Merah & $255,0,0$ & $0 \%$ (dibaca sebagai hijau dan ungu) \\
\hline 2 & Jingga/ Oranye & $255,127,0$ & $0 \%$ (dibaca sebagai merah) \\
\hline 3 & Kuning & $255,255,0$ & $80 \%$ \\
\hline 4 & Hijau & $0,255,0$ & $0 \%$ (dibaca sebagai kuning) \\
\hline 5 & Biru & $0,0,255$ & $0 \%$ (dibaca sebagai hijau dan kuning) \\
\hline 6 & Nila & $111,0,255$ & $0 \%$ (dibaca sebagai hijau) \\
\hline 7 & Ungu & $191,0,255$ & $0 \%$ (dibaca sebagai biru) \\
\hline
\end{tabular}

Pengujian berikutnya menggunakan styrofoam yang diberi warna pelangi dengan koordinat warna Red Green Blue (RGB). Hal ini dilakukan untuk mempersiapkan hasil perancangan perangkat lunak ini dalam pengujian yang nantinya melibatkan anak-anak usia bawah tiga tahun, dan hasil pengujian dapat dilihat pada Tabel 2.

Tabel 2. Pengujian menggunakan styrofoam

\begin{tabular}{|l|l|l|l|}
\hline No & Warna & Koordinat warna dalam RGB & Tingkat Keberhasilan \\
\hline 1 & Merah & $255,0,0$ & $80 \%$ \\
\hline 2 & Jingga/ Oranye & $255,127,0$ & $85 \%$ \\
\hline 3 & Kuning & $255,255,0$ & $87 \%$ \\
\hline 4 & Hijau & $0,255,0$ & $90 \%$ \\
\hline 5 & Biru & $0,0,255$ & $88 \%$ \\
\hline 6 & Nila & $111,0,255$ & $80 \%$ \\
\hline 7 & Ungu & $191,0,255$ & $80 \%$ \\
\hline
\end{tabular}

Pengujian terhadap pengguna dilakukan dengan cara membagikan kuesioner pada pengguna. Kuesioner terdiri dari 30 pernyataan dengan 30 orang responden. Skala Likert digunakan untuk mengukur sikap, pendapat dan persepsi seseorang atau sekelompok orang tentang fenomena sosial. Jawaban setiap pernyataan atau pertanyaan yang menggunakan skala Likert mempunyai gradasi dari sangat positif sampai sangat negatif di mana responden diberikan 5 pilihan jawaban. Adapun hasil pengujian terhadap pengguna dapat dilihat sebagai berikut:

Keterangan jawaban:

$1:$ Tidak Setuju

2 : Kurang Setuju

3 : Netral 
4 : Setuju

5 : Sangat Setuju

Perhitungan kuesioner menggunakan skala Likert. Kuesioner dibagi menjadi 2 bagian di mana pada bagian pertama responden diminta mengisi data diri, sedangkan bagian kedua berisi pernyataan yang menerangkan kesan responden terhadap aplikasi Pengenalan Warna. Pernyataan tersebut terbagi menjadi 3 bagian yaitu Tampilan Aplikasi, Proses Aplikasi, serta Hasil dan Kegunaan Aplikasi. Setiap pernyataan memiliki 5 pilihan jawaban.

Tabel 3. Hasil rekapitulasi kuesioner pengguna

\begin{tabular}{|c|c|c|c|c|c|c|}
\hline \multirow{2}{*}{ Pernyataan } & \multicolumn{5}{|c|}{ Jawaban } & \multirow{2}{*}{ Total } \\
\hline & 1 & 2 & 3 & 4 & 5 & \\
\hline Kesesuaian warna dan desain latar belakang & 0 & 1 & 5 & 22 & 2 & 30 \\
\hline Kesesuaian warna tulisan dengan latar belakang & 0 & 1 & 7 & 18 & 4 & 30 \\
\hline $\begin{array}{l}\text { Warna yang digunakan membuat tampilan lebih } \\
\text { menarik }\end{array}$ & 0 & 1 & 3 & 19 & 7 & 30 \\
\hline $\begin{array}{l}\text { Warna yang digunakan cocok sehingga tidak } \\
\text { mengganggu mata }\end{array}$ & 1 & 0 & 10 & 14 & 5 & 30 \\
\hline Ketepatan ukuran tulisan & 0 & 1 & 10 & 16 & 3 & 30 \\
\hline Ketepatan pemilihan jenis tulisan & 0 & 0 & 9 & 20 & 1 & 30 \\
\hline Ketepatan pemilihan warna tulisan & 0 & 0 & 3 & 24 & 3 & 30 \\
\hline Kesesuaian bentuk tombol & 0 & 2 & 9 & 16 & 3 & 30 \\
\hline $\begin{array}{l}\text { Tampilan sederhana sehingga membuat aplikasi } \\
\text { nyaman digunakan }\end{array}$ & 0 & 1 & 2 & 17 & 10 & 30 \\
\hline Proses aplikasi sangat sederhana & 0 & 1 & 9 & 17 & 3 & 30 \\
\hline Aplikasi mudah dipahami & 0 & 0 & 5 & 14 & 11 & 30 \\
\hline Aplikasi mudah digunakan & 1 & 0 & 5 & 12 & 12 & 30 \\
\hline Aplikasi merespon dengan cepat & 0 & 0 & 4 & 23 & 3 & 30 \\
\hline Aplikasi mudah dijalankan pada semua gadget & 1 & 0 & 1 & 24 & 4 & 30 \\
\hline Informasi yang disajikan mudah dimengerti & 0 & 0 & 6 & 16 & 8 & 30 \\
\hline Tata letak tampilan mudah dikenali & 1 & 0 & 8 & 15 & 6 & 30 \\
\hline $\begin{array}{l}\text { Tingkat pencahayaan sangat mempengaruhi hasil } \\
\text { dari aplikasi }\end{array}$ & 0 & 0 & 5 & 9 & 16 & 30 \\
\hline $\begin{array}{l}\text { Pengambilan gambar dimudahkan dengan adanya } \\
\text { bantuan timer }\end{array}$ & 0 & 1 & 10 & 16 & 3 & 30 \\
\hline $\begin{array}{l}\text { Pengambilan gambar dapat diulang dengan } \\
\text { mudah }\end{array}$ & 0 & 2 & 7 & 16 & 5 & 30 \\
\hline $\begin{array}{l}\text { Hasil warna yang diperoleh dengan aplikasi lebih } \\
\text { akurat }\end{array}$ & 0 & 2 & 7 & 16 & 5 & 30 \\
\hline Suara hasil sesuai dengan nama warna & 0 & 1 & 8 & 12 & 9 & 30 \\
\hline Aplikasi berfungsi dengan baik & 0 & 0 & 3 & 13 & 14 & 30 \\
\hline Aplikasi dapat mengenal berbagai macam warna & 0 & 0 & 4 & 16 & 10 & 30 \\
\hline $\begin{array}{l}\text { Aplikasi dapat digunakan untuk pembelajaran } \\
\text { pada anak }\end{array}$ & 0 & 0 & 6 & 13 & 11 & 30 \\
\hline $\begin{array}{l}\text { Orangtua dan anak sangat tertarik dan antusias } \\
\text { menggunakan aplikasi }\end{array}$ & 0 & 1 & 8 & 11 & 10 & 30 \\
\hline
\end{tabular}


Tabel 3 (lanjutan). Hasil rekapitulasi kuesioner pengguna

\begin{tabular}{|l|c|c|c|c|c|c|}
\hline \multirow{2}{*}{ Pernyataan } & \multicolumn{7}{|c|}{ Jawaban } & \multirow{2}{*}{ Total } \\
\cline { 2 - 9 } & 1 & 2 & 3 & 4 & 5 & \\
\hline $\begin{array}{l}\text { Anak bisa bermain sambil belajar mengenal } \\
\text { warna }\end{array}$ & 0 & 3 & 2 & 16 & 9 & 30 \\
\hline $\begin{array}{l}\text { Aplikasi membantu perkembangan daya ingat } \\
\text { anak akan warna }\end{array}$ & 0 & 2 & 3 & 14 & 11 & 30 \\
\hline $\begin{array}{l}\text { Aplikasi dapat membantu mengembangkan } \\
\text { kecerdasan intelektual anak }\end{array}$ & 1 & 1 & 5 & 13 & 10 & 30 \\
\hline \multicolumn{1}{|c|}{ Total } & 5 & 21 & 186 & 475 & 213 & 900 \\
\hline
\end{tabular}

Berikut hasil rekapitulasi kuesioner terhadap 30 responden dalam sebuah grafik ditampilkan pada Gambar 9.

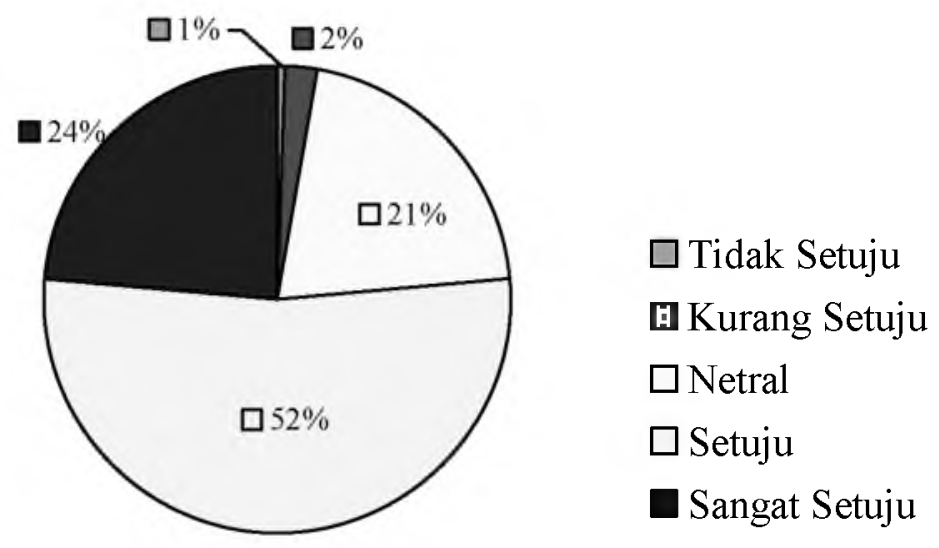

Gambar 9. Hasil Jawaban Terhadap 30 Responden

\section{Kesimpulan}

Dari hasil pengujian yang dilakukan dalam penelitian ini dapat diambil sebuah kesimpulan antara lain :

1. Proses image to speech yang terjadi dalam aplikasi yang digunakan dalam penelitian ini menggunakan text to speech setelah kamera berhasil mendeteksi warna pelangi.

2. Perangkat lunak ini sangat berguna untuk memberikan pembelajaran tentang warnawarna pelangi kepada anak-anak. 


\section{Daftar Pustaka}

Mastija, Wiwik Widajati, 2013, Peningkatan Kemampuan Pengenalan Konsep Warna Melalui Permainan Edukatif Dengan Styrofoam Pada Anak Usia Dini Kelompok A Di TK Islam Al Fajar Surabaya, Paud Teratai, Vol 2 Nomer 1.

Safaat H, Nazruddin, 2011, Android Pemrograman Aplikasi Mobile Smartphone dan Tablet PC Berbasis Android, Penerbit Informatika, Bandung.

Shalahuddin, M, Rosa A.S., 2008, Pemrograman J2ME Belajar Cepat Pemrograman Perangkat Telekomunikasi Mobile, Penerbit Informatika, Bandung.

http://library.binus.ac.id/eColls/eThesisdoc/Bab2/2011-2-00042-MTIF\%20Bab2001.pdf diakses tanggal Mei 2015.

http://lintas2u.com/index.php?route=product/product\&product_id=402 diakses tanggal 8 Juni 2015. 